International Research Journal of Management, IT \& Social Sciences
Available online at https://sloap.org/journals/index.php/irjmis/
Vol. 8 No. 3, May 2021, pages: 286-295
ISSN: 2395-7492
https://doi.org/10.21744/irjmis.v8n3.1677

\title{
Identification of National HRM Policy and Job Market Demand: Critical Review of Scientific Publication
}

\author{
A. M. Dadang a \\ Asmadianto ${ }^{b}$ \\ Sukowati Mudji Rahayu ${ }^{\mathrm{c}}$
}

\section{Article history:}

Submitted: 27 March 2021

Revised: 18 April 2021

Accepted: 9 May 2021

\section{Keywords:}

critical analysis;

government policy;

labor market needs;

sustainable HRM;

\begin{abstract}
This review study obtains much literature through a systemic search of data and information that covers the two variables above. The preparation and planning of human resources is a process that has been carried out systematically to improve human resources as the main asset worthy of being unemployable. On average, we find that this HR management is urgent to ensure the suitability between human resources and work, both in terms of quantity and quality that users are interested in, the study says. The study concludes that the preparation and Planning of Human Resources is a Process.
\end{abstract}

International research journal of management, IT and social sciences (C) 2021. This is an open access article under the CC BY-NC-ND license (https://creativecommons.org/licenses/by-nc-nd/4.0/).

\section{Corresponding author:}

Asmadianto,

Institut Ilmu sosial dan Ilmu Politik Yapis Biak, Indonesia

Email address: asmadianto1990@gmail.com

\footnotetext{
Institut Ilmu sosial dan Ilmu Politik Yapis Biak, Indonesia.Email: amdadang603@gmail.com

Institut Ilmu sosial dan Ilmu Politik Yapis Biak, Indonesia.

c Institut Ilmu sosial dan Ilmu Politik Yapis Biak, Indonesia.Email: sukowatirahayu@gmail.com 


\section{Introduction}

Expanding the distribution of Indonesia's human resources (HR) through national policies and improvement through education and training channels is one of the country's goals which is also supported through the annual state revenue and expenditure budget (APBN) (Yonezawa \& Shimmi, 2016; Marginson, 2016; Kondakci et al., 2018). Because the skilled and talented workforce indicated by market demand is the dream of a country in facing the demands of the international market in HR competition. Kaufman (2015), thus every public authority must take an essential role in preparing breakthroughs to produce quality human resources who are ready to enter the national and global job market. With a portion of $20 \%$ of the state budget for financial education plans, it is a form of commitment and substantial government support to improve the Indonesian nation's children (Hadijaya, 2013; Siregar \& Zain, 2020). The financial plan, among others, focuses on the Smart Indonesia program, School Operational Assistance, School/Classroom/Rehab Construction, and Bidik Misi Scholarship arrangements (Kasali et al., 2016; Beske et al., 2014). This program is very young but can be handled with high enthusiasm; it is believed that the output in the form of national human resources is in line with the demands of the ready-to-use job market.

As a support effort in the wheels of progress, strengthening human resources is increasingly necessary to rely on to have options to create imaginative, inventive, and highly competitive human resources in the global arena (Kirk, 2016; Bennett et al., 2017; Collings \& Isichei, 2018). The quality of human resources is relied on to have the choice to contribute and win in the worldwide competition. The Directorate General of State Assets plays a role in achieving the objectives of this organizational strategy. They have carried out their obligations and capacity as Government Investment Management in distributing school assets in the APBN, which the Public Service Agency supervises for the Education Fund Management Institution (BLU LPDP) (Pontoh et al., 2017; Rismita, 2020; Hifza \& Aslan, 2020; Hifza et al., 2020). The enormous value of APBN disbursements shows government assistance to improve the capacity of improving Indonesian human resources through the arrangement of education grants (Stadler et al., 2016; Gibson, 1998).

The government's seriousness in the HR program can be illustrated in the 2020 State Budget, a big challenge for DJKN as PPA BUN in the Field of Government Investment Management (Sivarajah et al., 2017; Mumpuni, 2014). Enrichment for exploration has begun to be disbursed in the 2019 State Budget. However, through the APBN portion, it is a blessing for universities that it is believed to encourage universities in Indonesia to improve their quality in boosting Indonesian and international human resources. The consequences of the enrichment of higher education, among others, will be used to provide an advanced administration and educational framework in order to form an advanced quality of education with world rankings (Wuryandani, 2014; Norreklit, 2000). It can create students who can rival other developed countries in the globalization market. The motivation behind the distribution of research blessings and lecture prizes in the APBN is needed to become a strategic rule for DJ KN in carrying out its capacity as P PA BUN. The DJKN section related to the assessment of the proposed BUN Fund Needs Indication is relied on so that it is in line to provide research blessings, namely expand the number and nature of human resources who are equipped to compete seriously around the world (Arifin \& Muslim, 2020). The state budget has a target to expand the significance and efficiency of exploration and become part of partners in research exercises that culminate in efforts to improve the human resources of the nation's children.

Specifically for support for research activities, it has been distributed since the 2019 State Budget. However, until the start of the drafting of the 2020 State Budget Bill, the institution for enriching the formation of the management in question had not been framed adequately to produce HR products following the will of national policy (Rohida, 2018; Putra et al., 2020). In connection with the role of higher education institutions, this has been regulated in the 2020 State Budget, where DJKN as a PPA BUN unit for Government Investment Management is needed to effectively oversee the arrangement of the formation/unit that will handle the enrichment of human resources.

If the LPDP BLU supervises the reserves for the enrichment of human exploration resources, this must be reexamined by the DJKN, considering that the LPDP BLU has issued allotments of utilization for research starting from the allotment of all public entities' businesses in BLU LPDP. In line with these HR development programs, Putri (2018) also said that the management program for changing activities to form superior guidance in school units would help boost HR. Because the proposed HR enrichment assignment has various impacts, especially research commitment at the tertiary level towards human resource development with a public financial budget, so the granting of authority must be formulated by a reputable service/institution approved to carry out and control the exploration of public funds for sustainable HR development (Las et al., 2018; Rumanti, 2020).

DJKN as PPA BUN in the Field of Government Investment Management is required to solicit the exploration enrichment readiness for the establishment of university management bodies and blessings so that these assets can be

Dadang, A. M., Asmadianto, A., \& Rahayu, S. M. (2021). Identification of national hrm policy and job market demand: critical review of scientific publication. International Research Journal of Management, IT and Social Sciences, 8(3), 286-295. https://doi.org/10.21744/irjmis.v8n3.1677 
supervised by an elite institutional unit so that they can be utilized following the objectives set for expanding the intensity and strengthening the quality of human resources (Mendoza \& Martins, 2006; Mumpuni, 2014). An establishment that will handle the exploration blessing reserve and the storage of college enrichment is a significant issue for achieving these asset objectives. In addition, considering that innovative tertiary education work is an administrative program that requires a large and reasonable asset allocation, it is hoped that there will be opportunities for channeling similar investment funds in the RAPBN (Irawan, 2018). Therefore, the total assets reserves of the organization's management must be resolved immediately, with the hope that the portion of these assets is in the next year's APBN; however, the investment of the management's establishment funds will not be improved (Cottineau et al., 2019; Getz \& Brown, 2006).

Expectations according to the obligations and elements of the DJKN must be resolved on the proposed assignment of similar budget reserves in the Draft State Budget for the coming years, Wight (2004). Central Government Financial Report. The Center for State Financial Accountability Studies by taking into account the objectives of the 2020 State Budget, which is identified with the acceleration of seriousness through progress and strengthening the readiness of human resources as a constant and creative cycle at every stage. The stages of achieving positive quality human resources require a certain period, such as the need for various support for state spending every year. In the 2020 RAPBN advertorial framework, which has been prepared by the Directorate General of Budget. Mumpuni (2014) the underlying program for improving the quality of human resources is the structure that underlies program development. In this stage that takes about ten years or will start in 2020 to 2030, the Government of Indonesia is needed to address segment difficulties through changes in all fields which are ideally used to support financial development, Abhimanyu (2013) both through exploitation and speculation and creation - and strengthening the intensity of Indonesian human resources.

If the ten-year stage has been carried out, the following stages are a period of change for intensity strengthening, which will be completed from 2031 to 2035 (Amedi, 2018). In this stage, the Government of Indonesia is relied on to have these options to improve the nature of human resources to be more aggressive, empowering the framework that has been made up. So that it tends to be operated ideally to provide more comprehensive efficiency and support changes in industrialization, and a comprehensive social security program has begun to be implemented (Hayati \& Yulianto, 2020). The last stage is the achievement of Advanced Indonesia in the period 2036 to 2045. In this stage, it is believed that Indonesia wants to get out of the central salary trap so that Indonesia is ready to turn into a country that is created, independent, just, and prosperous (Meriam, 2020).

Another job that DJKN can play as PPA BUN is for Government Investment Management to help achieve research enrichment sharing. For this reason, Samsuni (2017) study is also of relevance where Human Resource management has become a national responsibility at the tertiary level by observing and estimating the feasibility of projects that have been intended to be completed with these distribution assets by retaining and utilizing the wealth of the Budget User Authority (KPA) if the unit that handles blessings has been established and is running. Sinambela (2021) in Human Resource management through building a solid work team to improve performance. Types of observations and assessments carried out by DJKN as PPA BUN on KPA on the use of Government Business Reserves assignments can be through an assessment of the proposed Fund Need Indication, particularly an assessment of program information sources, results, and results completed by beneficiaries (Setiawan, 2016) with speculation. Government. The role of DJKN as PPA BUN for Government Investment Management has a significant effect on the success of project implementation to build the intensity of Indonesian human resources through this cycle.

\section{National HCI Index}

Indonesia's record of human progress has improved compared to the previous two years (Kesuma \& Astuti, 2020). Indonesia's 2020 score received 0.54, up from 0.53 in 2018. HCI is one of the World Bank projects (Faedlulloh et al., 2020). Intended to clarify how welfare conditions and training can support the efficiency of society in the future. It consolidates the possibility of living up to 5 years of age, quality and amount of training, and well-being, including barrier issues. The 2020 HCI score is prepared based on new information and is extended for each part until March 2020 (Seto et al., 2015).

Indonesia's position in 111 out of 189 countries on the Human Development Index (HDI) in 2020 Indonesia is in 87 th position out of 174 countries studied. Since 2009 , the government as a public servant has spent $20 \%$ of the state budget for education and training reserves. In 2020, the government will distribute educational assets of IDR 505.8 trillion for various educational needs, including compensation, accreditation, and school activities (Putriyani et al., 2018). Even though for more than ten years, the government has shed enormous assets for the advancement of the 
region. Schools, however, do not yet have the option to improve the nature of their human resources. Amid the Covid19 pandemic, it is progressively felt that welfare and training issues have seriously affected the country's capacity to maintain its administration (Rodiyah et al., 2018). Many families cannot provide the office and foundation their children need for separate study. This condition is expected to be exacerbated by the number of families falling into poverty due to increased unemployment. Public agencies should focus their spending plans on essential items that individuals need. The problems and difficulties facing the government are enormous and complex. If the government neglects to determine the necessary posts, the position will be increasingly left behind, which will bring the nature of human resource intensity to the index in the Asian region (Lengkong et al., 2019).

\section{Urgency Human resources}

Results-based schools are seen as ideal advances in the current elements of education and training. A collaboration workshop between the Education Accountants Compartment (KAPd) of IAI Universitas Airlangga and the Faculty of Economics and Business Association was studied (Saputri \& Tumangger, 2019). The agreement at the meeting underlined that the influx of experts and industrial relations so far has been used to create human resource capabilities must be increased. The implementation of the KAPd IAI can be described as coaching experts on the government's attitude at the MPR RI Plenary Session. IAI has identified five improvement centers for 2020-2024, which consist of human resource development, infrastructure development, simplification of regulations, simplification of the bureaucracy and the economy (Syarifuddin, 2020; Putra, Liriwati, et al., 2020; Sudarmo et al., 2021).

In terms of acceleration and emergency of Indonesian human resources, the government requests that bookkeeping separate complexity into clarity to increase understanding of a prosperous society (Puspaningrum \& Yuliastina, 2020). Mastering change to prepare for the future is an essential program for DPN IAI for the 2018-2022 period to ensure that this summons can pass through difficulties and make progress in the future. Initiative 2 instructs the IAI to create bookkeeping and specialist education that mandates business innovation.

Experts warn that if the presence of human-made awareness, internet business, enormous information, fintech, blockchain, and cryptographic money, will change the bookkeeping approach and turn into advanced bookkeeping (Wahyu \& Salam, 2020). Bookkeepers must be prepared for this change. Bookkeeping now and then must dominate enormous information, computerized steps, distributed computing, and have the option of running cycles progressively. The Covid-19 pandemic has triggered rapid fundamental changes, both in schools and in the world of work. Distance learning, increasing the pace of progressive change in all businesses, to the pressure to redesign capabilities, among others, have changed (Wulandjani \& Setiyowati, 2021).

\section{Focus 2020}

The government has entered an important year for the long-term development plan towards 2024 in 2020 . The first five years of the national development system 2005-2025 have been devoted to developing Indonesian human resources. According to Ratnaningsih (2016) a paradigm shift in the national development program is one state's legal human resources following constitutional amendments. Indonesia has confirmed this, precisely regulation Number 17 of 2007 concerning the Long-Term National Development Plan 2005-2025. Similarly, based on the vision and direction of the National (2004), where the vision and direction of future development from 2005 to 2025. As a result, the development progress made in the last five years has resulted in positive outcomes. As a result, in the second quarter of the fourth quarter of 2019, Indonesia's economic development reached 5.04 percent, up from 4.88 percent in 2015. According to Li et al. (2020) the swelling can be maintained stably in the range of 3 percent over five years. Similarly, the priority for lowering the open unemployment rate fell from 6.18 percent in 2015 to 5.28 percent in August 2019 . Furthermore, the 1-digit need figure, which could be reduced to less than 10\%, reached 9.41 percent (Rofiq, 2019).

Imawan et al. (2019) views on public accountants provide an understanding that experts such as universities and other training institutions to strengthen and expand relations with industries that will recruit more prospective workers will be very important in creating the quality and capability of Indonesian human resources. This must be supported, given that work change patterns or elements rapidly, while educational programs have not changed significantly (Widiansyah, 2018). Until now, the university itself has a human resource improvement program, but the cooperation program of experts coordinated with universities is also essential, giving appreciation to improvements to plans and schedules for education and training. It is well known that the scholastic area-based job vacancies are minimal. Agustin (2013) supports the notion that bachelor degree (S1) graduates need to be prepared by psychology in facing the world

Dadang, A. M., Asmadianto, A., \& Rahayu, S. M. (2021). Identification of national hrm policy and job market demand: critical review of scientific publication. International Research Journal of Management, IT and Social Sciences, 8(3), 286-295. https://doi.org/10.21744/irjmis.v8n3.1677 
of work in college students. Studies such as identification of the world of work and national human resources have been carried out.

\section{Materials and Methods}

This review study aims to identify how the relationship between the policies of the national HR authority and the demands of the world of work through a critical review of several international publications related to HR preparation issues with the desires of the labor market, especially public services. This study obtained a lot of data input through systemic electronic search, which covers the two main problems above. Searching for adequate publication data with the help of electronic searches of the Google Scholar application released is relatively new between 2010 and 2021. In order to find the findings for this study, we first carried out a preliminary reading and understood the research problem carefully. Furthermore, the analysis process involves a data coding system, critical evaluation, and in-depth interpretation with a phenomenological approach to achieve the validity and reliability of our findings. Since our study is related to review studies, the appropriate design is descriptive qualitative as studied in human resource governance studies and other employability studies (Leech \& Onwuegbuzie, 2011).

\section{Results and Discussions}

To get an understanding of the suitability of the two variables above, Lis (2012) findings regarding the importance of corporate social obligations regarding executives' valuable human assets are worth considering. Investigate hierarchical attractiveness as determinants in the choice of representatives of (potential) bosses. The examination explores job seekers' impressions of the company's social obligations. CSR responsibility is a viable tool for attracting the expected representation. If associations provide continuous HRM practice, they can turn into business decisions. This paper provides evidence that each part of CSR has a remarkable impact on hierarchical attractiveness. The exams are distributed in the Sustainable Human Resource Management diary.

The findings of Nilsson \& Ellström (2012) support how close the relationship is between the world of work and human resource capabilities. They say that this is a significant challenge for the HRD education and training environment. They added that the world of work is said to be by constant demand and massive innovation. HR skills are perceived as a new strategy in which every company can prepare demands related to higher complexity. Their findings clearly state that job skills can no longer be offered to carry out every worker's duties and achieve optimal results. Skills and competencies are the basis for obtaining employment, but their recommendation proposes various models in which competence includes each individual's social indicators, associations, and reverse relationships. Their conclusions that the multiple implications of skills and substance of expertise are urgent for the practical consequences of focusing human asset enhancement exercises, such as preparation for and pursuing new scientific advances following the demands of the times.

Chams \& García-Blandón (2019) also studied the importance of executives retaining human assets to accept progress goals that can be supported. Companies increasingly recognize the importance of social, moral, and environmental targets. The goal of practical improvement is achieved through the adoption of new environmental strategies by human resource associations. This methodical writing survey looks at the critical work of Sustainable Human Resource Management in building a decent workplace. Many definable suggestions can be tried out observationally in future examinations, say the researchers. The reason that potential future bearings are proposed for additional exploration in the field of economic administration.

The study of Hecklau et al. (2016) also gained an understanding that all methodologies that cover HR assets are the main actors in the Industry 4.0 era. This new critical approach demands that all human resources, including executives, are needed in advancing the company. This finding has fulfilled the requirements of HR managers to move their abilities to the workspace with more effective measures. Understanding the importance of methodology for representative capability is illustrated in this commitment. Likewise, Wang \& Tsai (2014) examined the employability of hospitality graduates from the point of view of student competence and industrial needs. The study examines the impressions of senior students and industry heads about employability in business practice. Both students and need confidence in their employability, especially in the area of expert administrative skills. Similarly, accommodated the idea of working with the employability of hospitality graduates in Taiwan. 
Broetje et al. (2020) studied the critical occupation requests and assets of nursing staff: An integrative audit of surveys. The point of our survey is to recognize the critical occupation assets and requests of nursing staff by coordinating discoveries from recently distributed audits as per the JD-R model. Understanding these is exceptionally important given the constantly expanding pressure in nursing work and the difficulties of medical services associations in enlisting qualified staff. It is likewise a significant advance toward creating focused work environment intercessions. Topical investigation recognized work over-burden, absence of formal prizes, work-life obstruction, administrator backing, and reasonable and legitimate administration.

Furthermore, the study of Eriksson et al. (2021) can explain that user requests and HR utilitarian assets direct employers and registered nursing staff not to be easily excluded because they are not qualified. To explore how job demands and HR assets work together with each other can be interconnected. This study predicts that the goal of leaving between collaborator and registered nurse care will not occur if HR is following user expectations. It is answered that the request for job providers is not anticipated by HR colleagues so that workers are not easily removed, while HR assets anticipate job user decisions. Several HR assets help direct the relationship between users' demand and HR expectations to continue to work. Others were not ready.

Evidence by Collie et al. (2018) that the compatibility between HR preparation and industry benefits can be done through the support and flexibility of the independence of instructors who are transparent and understand what is best given to the HR governance program. Examination of the use of the HR asset model and applicable job requests to address gaps and work environment responsibilities. They examined the extent to which support towards self-reliance was related to versatility and whether both were associated with reducing the high gap so that it stopped working. With an example of 164 Australian optional teachers, they led the presentation of the primary conditions. The findings show that HR preparation is unequally yoked with fatigue and withdrawal and is strongly associated with transformation.

Furthermore, the study of Wilks \& Hemsworth (2012) proves refined expertise as a critical skill in hospitality further education by coordinating with industry demand and supply from the results of government policies through educational institutions. This investigation seeks to identify abilities seen as fundamental to the pioneers of the job accommodation industry. It offers some reflections on the HR further education environment. The investigation examines the design of the Portuguese undergraduate certificate to discuss whether the current instructive offerings are of explicit industry interest. It also offers a reflection on the current accommodation status of the executive program in Portugal. This researcher argues that the investigation findings suggest that the training by current education institutes offered to Portuguese students does not address HR issues leading to serious business with serious preparation.

The study of Hecklau et al. (2016) also gained an understanding that all methodologies that cover HR assets are the main actors in the Industry 4.0 era. This new critical approach demands that all human resources, including executives, are needed in advancing the company. This finding has fulfilled the requirements of HR managers to move their abilities to the workspace with more effective measures. Understanding the importance of methodology for representative capability is illustrated in this commitment. Likewise, Wang \& Tsai (2014) examined the employability of hospitality graduates from the point of view of student competence and industrial needs. The study examines the impressions of senior students and industry heads about employability in business practice. Both students and need confidence in their employability, especially in the area of expert administrative skills. Similarly, accommodated the idea of working with the employability of hospitality graduates in Taiwan.

\section{Discussion}

\section{The importance of HR for the company}

Human resources are essential elements so that a business or company can run well to achieve the company's final goals. Without the elements of HR governance that are ready, this or the quality is not good; the company will find it challenging to run and operate properly even though other resources have been fulfilled. For this reason, the government in every country understands and has entrusted the provision and preparation of superior human resources to educational institutions, which are generally recognized as tertiary institutions. Then it is the institution that sets the quality standards for human resources after receiving support in the form of significant budget investments and policy products that regulate the conformity of policies and services by university institutions and the demand for the world of work as the user.

Identify this suitability, and this study can explain that most of the research evidence we found has confirmed that the company or the employer will want to employ workers who have high and well-qualified human resources. In this

Dadang, A. M., Asmadianto, A., \& Rahayu, S. M. (2021). Identification of national hrm policy and job market demand: critical review of scientific publication. International Research Journal of Management, IT and Social Sciences, 8(3), 286-295. https://doi.org/10.21744/irjmis.v8n3.1677 
case, the government has allocated many APBN funds for training institutions such as high schools to prepare programs and ready-to-use human resources. This matter is reviewed by Widodo (2016) with the theme how the portrait of Indonesian human resources and their readiness to face the Asian economic business community. For example, the same findings, for example, Sujanto (2015) analyzed the competency standards of course implementing agencies with the demand for HR complexity in the ASEAN free economy era.

Furthermore, universities are recognized as actors who receive an abundance of HR preparation policies, emphasizing the importance of actors' role in realizing policies in preparing human resources needed by users or industries. Policies include studies on the use of technical analysis, research, and advocacy in producing human resources according to the demands of the world of work. However, the reality is that not all policies and policy implementations can be implemented with the right target. So it is not so surprising that the quality of human resources is often at odds with the demands of the professional world, especially now that employers can freely recruit prospective workers globally so that in the end, competition for human resources is no longer a national issue but a global issue and all demanding complexities. For this, the findings of Yusrie et al. (2021) in public policy projects and the appearance of educational administration, and the complexity of developing reliable human resources.

\section{Conclusion}

At the end of this section, we can conclude that the objective of this study is to identify national HRM policies and the demands of the labor market needs with the critical review method on several international scientific publications. So we can conclude that the purpose of this study is answered that there is a match between national policies by the state delegated to tertiary institutions so that human resources can be prepared, especially human resources in public services. However, not all of our studies can report a close relationship. This means that there are also failures in human resource management that are not following the demands of the world of work. This complexity is faced by both the human resources themselves and the high demand by employers for more competitive work opportunities between countries.

\section{Conflict of interest statement}

The author(s) declared that they have no competing interests.

\section{Statement of authorship}

The author(s) have a responsibility for the conception and design of the study. The author(s) have approved the final article.

\section{Acknowledgments}

We authors would like to appreciative all support for colleagues and academic supervisor for the idea and feedback from the beginning up to completion. Similarly to funding support the minister of research and technology. Without their supports this paper will not be done as planned. 


\section{References}

Abhimanyu, P. S. (2013). Defining the Determinant-like Function for $\mathrm{m}$ by $\mathrm{n}$ Matrices Using the Exterior Algebra. Advances in Applied Clifford Algebras, 23(4), 787-792.

Agustin, V. (2013). Kompetensi Lulusan Sarjana Strata 1 (S1) Psikologi dalam Menghadapi Dunia Kerja Pada mahasiswa Perguruan Tinggi "X". Calyptra, 1(1), 1-34.

Amedi, A. M. (2018). Analisis Politik Hukum Pendidikan Dasar di Indonesia Demi Menyongsong Era Tujuan Pembangunan Berkelanjutan (Sustainable Development Goals/SDGs). Padjadjaran Law Review, 6.

Arifin, S., \& Muslim, M. O. H. (2020). Tantangan Implementasi Kebijakan “Merdeka Belajar, Kampus Merdeka” pada Perguruan Tinggi Islam Swasta di Indonesia. Jurnal Pendidikan Islam Al-Ilmi, 3(1).

Bennett, M. M., Beehr, T. A., \& Ivanitskaya, L. V. (2017). Work-family conflict: Differences across generations and life cycles. Journal of Managerial Psychology.

Beske, P., Land, A., \& Seuring, S. (2014). Sustainable supply chain management practices and dynamic capabilities in the food industry: A critical analysis of the literature. International journal of production economics, 152, 131143. https://doi.org/10.1016/j.ijpe.2013.12.026

Broetje, S., Jenny, G. J., \& Bauer, G. F. (2020). The key job demands and resources of nursing staff: An integrative review of reviews. Frontiers in Psychology, 11.

Chams, N., \& García-Blandón, J. (2019). On the importance of sustainable human resource management for the adoption of sustainable development goals. Resources, Conservation and Recycling, 141, 109-122.

Collie, R. J., Granziera, H., \& Martin, A. J. (2018). Teachers' perceived autonomy support and adaptability: An investigation employing the job demands-resources model as relevant to workplace exhaustion, disengagement, and commitment. Teaching and Teacher Education, 74, 125-136.

Collings, D. G., \& Isichei, M. (2018). The shifting boundaries of global staffing: Integrating global talent management, alternative forms of international assignments and non-employees into the discussion. The International Journal of Human Resource Management, 29(1), 165-187.

Cottineau, C., Finance, O., Hatna, E., Arcaute, E., \& Batty, M. (2019). Defining urban clusters to detect agglomeration economies. Environment and Planning B: Urban Analytics and City Science, 46(9), 1611-1626.

Eriksson, A., Jutengren, G., \& Dellve, L. (2021). Job demands and functional resources moderating assistant and Registered Nurses' intention to leave. Nursing Open, 8(2), 870-881.

Faedlulloh, D., Maarif, S., Meutia, I. F., \& Yulianti, D. (2020). Birokrasi dan Revolusi Industri 4.0: Mencegah Smart ASN menjadi Mitos dalam Agenda Reformasi Birokrasi Indonesia. Jurnal Borneo Administrator, $16(3)$, 313-336.

Gibson, H. J. (1998). Sport tourism: a critical analysis of research. Sport management review, 1(1), 45-76. https://doi.org/10.1016/S1441-3523(98)70099-3

Getz, D., \& Brown, G. (2006). Critical success factors for wine tourism regions: a demand analysis. Tourism management, 27(1), 146-158. https://doi.org/10.1016/j.tourman.2004.08.002

Hadijaya, Y. (2013). Menyusun Strategi Berbuah Kinerja Pendidik Efektif.

Hayati, N., \& Yulianto, E. (2020). Peranan Keuangan Berkelanjutan Pada Industri Perbankan Dalam Mendukung Sustainable Development Goals. Jurnal Akuntansi Bisnis Dan Ekonomi, 6(1), 1633-1652.

Hecklau, F., Galeitzke, M., Flachs, S., \& Kohl, H. (2016). Holistic approach for human resource management in Industry 4.0. Procedia Cirp, 54, 1-6.

Hifza \& Aslan. (2020). The Model of Competitive Advantage Development in Private Islamic Education Institutions dalam "BASA 2019: Proceedings of the Third International Seminar on Recent Language, Literature, and Local Culture Studies, BASA, 20-21 September 2019, Surakarta, Central Java, Indonesia. European Alliance for Innovation.

Hifza, Juliana, Palapa, A., Maskur, \& Aslan. (2020). The Strategic Foundation for Competitive Excellent Development in Integrated Islamic Primary Schools in Indonesia. International Journal of Advanced Science and Technology, 29(12s), 1747-1753.

Imawan, A., Irianto, G., \& Prihatiningtias, Y. W. (2019). Peran akuntabilitas pemerintah desa dalam membangun kepercayaan publik. Jurnal Akuntansi Multiparadigma, 10(1), 156-175.

Irawan, D. E. (2018). Kajian Pendidikan Tinggi IDRI untuk DPR RI dan Ristek Dikti 2018.

Kasali, R., Mas, M., Umar, B. W., Kartodihardjo, H., Indrayana, D., Firmanzah, F., Saefuddin, A., Nugroho, H., Bhakti, I. N., \& Isra, S. (2016). Bunga Rampai Opini Guru Besar Antikorupsi: Memperkuat \& Mempertahankan KPK. Indonesia Coruption Watch.

Kaufman, B. E. (2015). Market competition, HRM, and firm performance: The conventional paradigm critiqued and reformulated. Human Resource Management Review, 25(1), 107-125.

Dadang, A. M., Asmadianto, A., \& Rahayu, S. M. (2021). Identification of national hrm policy and job market demand: critical review of scientific publication. International Research Journal of Management, IT and Social Sciences, 8(3), 286-295. https://doi.org/10.21744/irjmis.v8n3.1677 
Kesuma, M. N., \& Astuti, E. T. (2020). Kajian indeks modal manusia dan peranannya dalam pertumbuhan ekonomi indonesia 2015-2018. Seminar Nasional Official Statistics, 2020(1), 817-824.

Kirk, S. (2016). Career capital in global Kaleidoscope Careers: The role of HRM. The International Journal of Human Resource Management, 27(6), 681-697.

Kondakci, Y., Bedenlier, S., \& Zawacki-Richter, O. (2018). Social network analysis of international student mobility: Uncovering the rise of regional hubs. Higher Education, 75(3), 517-535.

Las, I., Soedjana, T. D., Soeparno, H., Heriawan, R., Suryana, A., Jamal, E., Mudiarta, K. G., Kariyasa, K., Ariani, M., \& Arsanti, I. W. (2018). Sinergi Sistem Penelitian dan Inovasi Pertanian Berkelanjutan. IAARD Press.

Leech, N. L., \& Onwuegbuzie, A. J. (2011). Beyond constant comparison qualitative data analysis: Using NVivo. School Psychology Quarterly, 26(1), 70.

Lengkong, S. M. K., Rotinsulu, D. C., \& Walewangko, E. N. (2019). Pengaruh Alokasi Anggaran Pendidikan Dan Kesehatan Terhadap Indeks Pembangunan Manusia Dan Dampaknya Terhadap Pertumbuhan Ekonomi Kota Bitung. Jurnal Pembangunan Ekonomi Dan Keuangan Daerah, 19(2).

Li, D., Wang, Q., Member, I., \& Kong, F. (2020). Superpixel-feature-based multiple kernel sparse representation for hyperspectral image classification. Signal Processing, 176, 107682.

Lis, B. (2012). The relevance of corporate social responsibility for a sustainable human resource management: An analysis of organizational attractiveness as a determinant in employees' selection of a (potential) employer. Management Revue, 279-295.

Marginson, S. (2016). The dream is over: The crisis of Clark Kerr's California idea of higher education (Vol. 260). University of California Press Berkeley, CA.

Mendoza, G. A., \& Martins, H. (2006). Multi-criteria decision analysis in natural resource management: a critical review of methods and new modelling paradigms. Forest ecology and management, 230(1-3), 1-22. https://doi.org/10.1016/j.foreco.2006.03.023

Meriam, M. (2020). Kajian kerja sama di bidang sumber daya manusia dari perspektif liberalisme studi kasus: Indonesia dengan Australia, Jepang, Korea Selatan dan China [PhD Thesis]. Universitas Pelita Harapan.

Mumpuni, M. (2014). Pengantar Pengelolaan Keuangan Negara. Jakarta: Sekolah Tinggi Akuntansi Negara.

Norreklit, H. (2000). The balance on the balanced scorecard a critical analysis of some of its assumptions. Management accounting research, 11(1), 65-88. https://doi.org/10.1006/mare.1999.0121

Nilsson, S., \& Ellström, P.-E. (2012). Employability and talent management: Challenges for HRD practices. European Journal of Training and Development.

Pontoh, J., Ilat, V., \& Manossoh, H. (2017). Analisis Pengelolaan Dana Bantuan Operasional Sekolah (BOS) pada Satuan Pendidikan Dasar di Kota Kotamobagu. Jurnal riset akuntansi dan auditing" goodwill", 8(2).

Puspaningrum, I. I., \& Yuliastina, R. (2020). Implementasi peraturan bupati sumenep n0. 14 tahun 2019 tentang percepatan penanggulangan stunting (Studi di Dinas Kesehatan Kabupaten Sumenep). Public Corner, 15(2), 2537.

Putra, P., Liriwati, F. Y., Tahrim, T., Syafrudin, S., \& Aslan, A. (2020). The Students Learning from Home Experiences during Covid-19 School Closures Policy In Indonesia. Jurnal Iqra': Kajian Ilmu Pendidikan, 5(2), 30-42. https://doi.org/10.25217/ji.v5i2.1019

Putra, P., Mizani, H., Basir, A., Muflihin, A., \& Aslan, A. (2020). The Relevancy on Education Release Revolution 4.0 in Islamic Basic Education Perspective in Indonesia (An Analysis Study of Paulo Freire's Thought). Test Engineering \& Management, 83, 10256-10263.

Putri, M. L. (2018). Implementasi manajemen perubahan pada program kelas unggulan di madrasah tsanawiyah negeri ( $m$ ts $n$ ) 2 bandar lampung [PhD Thesis]. UIN Raden Intan Lampung.

Putriyani, N., Nugroho, K. S., \& Riswanda, R. (2018). Implementasi program bantuan operasional sekolah tahun 2016 pada jenjang pendidikan sekolah dasar di upt dinas pendidikan dan kebudayaan kecamatan karangtanjung kabupaten pandeglang [PhD Thesis]. Universitas Sultan Ageng Tirtayasa.

Ratnaningsih, E. (2016). Perubahan Paradigma Pembangunan Hukum Nasional Pasca Amandemen Konstitusi. Pakuan Law Review, 4(1).

Rismita, R. (2020). The Management Of The Education Operational Grant And Its Effects On School Development. JPI (Jurnal Pendidikan Indonesia), 9(2), 328-338.

Rodiyah, A., Dirlanudin, D., \& Cadith, J. (2018). Analisis swot terhadap dinas pendidikan dan kebudayaan kota serang dalam menanggulangi pemberantasan buta aksara di kota serang [PhD Thesis]. Universitas Sultan Ageng Tirtayasa.

Rofiq, A. (2019). Kemajuan Ekonomi Indonesia Isu Strategis, Tantangan, dan Kebijakan. PT Penerbit IPB Press. 
Rohida, L. (2018). Pengaruh era revolusi industri 4.0 terhadap kompetensi sumber daya manusia. Jurnal Manajemen Dan Bisnis Indonesia, 6(1), 114-136.

Rumanti, I. A. (2020). Breeding of abiotic tolerant varieties with high grain quality to meet the consumer preference at rice swampy land. IOP Conference Series: Earth and Environmental Science, 484(1), 012029.

Samsuni, S. (2017). Manajemen sumber daya manusia. Al-Falah: Jurnal Ilmiah Keislaman Dan Kemasyarakatan, $17(1), 113-124$.

Saputri, R. A., \& Tumangger, J. (2019). Hulu-Hilir Penanggulangan Stunting di Indonesia. Journal of Political Issues, $1(1), 1-9$.

Setiawan, R. I. (2016). Pengembangan sumber daya manusia di bidang pariwisata: Perspektif potensi wisata daerah berkembang. Jurnal Penelitian Manajemen Terapan (PENATARAN), 1(1), 23-35.

Seto, S., Nita, Y., \& Triana, L. (2015). Manajemen Farmasi 2: Edisi 4: Lingkup apotek, farmasi rumah sakit, industri farmasi, pedagang besar farmasi. Airlangga University Press.

Sinambela, L. P. (2021). Manajemen Sumber Daya Manusia: Membangun tim kerja yang solid untuk meningkatkan kinerja. Bumi Aksara.

Siregar, M., \& Zain, F. (2020). Kontribusi Rekrutmen, Pemberian Hadiah dan Hukuman Terhadap Produktivitas Kerja Guru Di Mts N Kota Medan [PhD Thesis]. Universitas Islam Negeri Sumatera Utara.

Stadler, C., Wieser, M., \& Kirk, K. (2016). Psychodrama. Empirical Research and Science 2. Springer.

Sudarmo, Nugraha, M. S., Mardhiah, R. I.liow, F. E., \& Aslan. (2021). The Identification of Online Strategy Learning Results While Students Learn from Home During the Disruption of the COVID-19 Pandemic in Indonesia. Journal of Contemporary Issues in Business and Government, 27(2), 1950-1956. https://doi.org/10.47750/cibg.2021.27.02.205

Sivarajah, U., Kamal, M. M., Irani, Z., \& Weerakkody, V. (2017). Critical analysis of Big Data challenges and analytical methods. Journal of Business Research, 70, 263-286. https://doi.org/10.1016/j.jbusres.2016.08.001

Sujanto, A. (2015). Analisis Kesesuaian Standar Kompetensi Pengelola Kursus dengan Tuntutan Kompetensi Tenaga Kerja pada Era Masyarakat Ekonomi ASEAN (MEA) 2015. Infokam, 11(4).

Syarifuddin, M. (2020). Transformasi Gigital Persidangan di Era New Normal: Melayani Pencari Keadilan di masa Pandemi Covid-19.

Wahyu, W., \& Salam, R. (2020). Komitmen organisasi (Kajian: Manajemen Sumber Daya Manusia).

Wang, Y.-F., \& Tsai, C.-T. (2014). Employability of hospitality graduates: Student and industry perspectives. Journal of Hospitality \& Tourism Education, 26(3), 125-135.

Widiansyah, A. (2018). Peranan Sumber Daya Pendidikan sebagai Faktor Penentu dalam Manajemen Sistem Pendidikan. Cakrawala-Jurnal Humaniora, 18(2), 229-234.

Widodo, H. (2016). Potret pendidikan di Indonesia dan kesiapannya dalam menghadapi masyarakat ekonomi Asia (MEA). Cendekia: Jurnal Kependidikan Dan Kemasyarakatan, 13(2), 293-308.

Wight, C. (2004). State agency: Social action without human activity? Review of International Studies, 30(2), 269280.

Wilks, D., \& Hemsworth, K. (2012). Soft skills as key competencies in hospitality higher education: Matching demand and supply. Tourism \& Management Studies, 7, 131-139.

Wulandjani, H., \& Setiyowati, H. (2021). Agility organisasi dan praktik human resources management terhadap dampak disruption semasa COVID 19. Valuasi: Jurnal Ilmiah Ilmu Manajemen Dan Kewirausahaan, 1(1), 216226.

Wuryandani, D. (2014). Peluang dan tantangan SDM Indonesia menyongsong era masyarakat ekonomi asean. Info Singkat Ekonomi Dan Kebijakan Publik, 6(17), 13-16.

Yonezawa, A., \& Shimmi, Y. (2016). Transformation of university governance through internationalization: Challenges for top universities and government policies in Japan. In Matching Visibility and Performance (pp. 101-118). Brill Sense.

Yusrie, C. S., Aminah, S., Wasliman, I., \& Sauri, R. S. (2021). Kebijakan Publik dan Kinerja Birokrasi Pendidikan Dalam Kompleksitas Perkembangan. Jurnal Dirosah Islamiyah, 3(2), 126-143.

Dadang, A. M., Asmadianto, A., \& Rahayu, S. M. (2021). Identification of national hrm policy and job market demand: critical review of scientific publication. International Research Journal of Management, IT and Social Sciences, 8(3), 286-295. https://doi.org/10.21744/irjmis.v8n3.1677 